\title{
Persepsi Masyarakat Terhadap Eksistensi Pak Ogah
}

\author{
Hajerni \\ Nursalam \\ Universitas Muhammadiyah Makassar \\ nursalam@unismuh.ac.id \\ Muhammad Akhir \\ Universitas Muhammadiyah Makassar \\ muhammadakhir@unismuh.ac.id
}

\begin{abstract}
ABSTRAK
Penelitian ini merupakan penelitian sosial budaya.Jenis Penelitian yang digunakan adalah metode penelitian kualitatif dengan cara penentuan sampel melalui teknik Purposive Samplingdengan memilih beberapa informan yang memiliki kriteria yang telah ditentukan oleh peneliti yakni yang mengetahui tentang aktifitas pak ogah di kota Makassar tersebut. Penelitian ini bertujuan untuk mengetahui persepsi masyarakat terhadap keberadaan pak ogah di kota Makassar tersebut. Penelitian ini bersifat deskriptif kuantitatif, tentang Persepsi Masyarakat terhadap Keberadaan Pak Ogah di Kota Makassar. Peneliti akan menganalisis data atau informasi yang dikumpulkan dari hasil observasi, wawancara dan dokumentasi yaitu dengan mengklasifikasikan data berdasarkan kriteria-kriteria tertentu yang telah ditentukan oleh peneliti kemudian membandingkan data atau informasi dari setiap sumber-sumber yang peneliti dapatkan dilapangan serta mencari hubungan antara data atau informasi yang diperoleh yang ada kaitannya dengan focus penelitian, dan terakhir penarikan kesimpulan dan verifikasi.Hasil penelitian menunjukkan bahwa persepsi masyarakat terhadap keberadaan pak ogah dalam setiap kalangan memiliki pandangan masing-masing, namun apabila kita mengutamakan keamanan dan kenyamanan di jalan maka sebaiknya polisi lalu lintaslah yang mengatur kendaraan tersebut karena ini merupakan tugas, tanggung jawab, serta wewenangnya, karena ia adalah lembaga resmi selain dari pada itu yang tidak memiliki wewenang di jalan bersifat ilegal seperti aktivitas pak ogah tersebut.
\end{abstract}

Kata Kunci: Persepsi, Masyarakat, Pak Ogah.

\section{PENDAHULUAN}

Pertumbuhan laju penduduk menuntut manusia untuk berfikir bagaimana mereka mampu mempertahankan kehidupannya di tengah masyarakat.Kepadatan penduduk kian tahun kian meningkat.Modernisasi di zaman sekarang ini telah nampak kita rasakan, baik itu teknologi maupun informasi bahkan transportasi pun mengambil bagian didalamnya sebagai laju perkembangan ekonomi. Semakin kompleks kehidupan masyarakat maka akan semakin banyak hal baru pula yang akan muncul di tengah masyarakat tersebut, dan membuat masyarakat untuk selalu berfikir apa yang mampu mereka lakukan untuk mengambil peran agar mampu bertahan di kehidupan sekarang dan di masa yang akan datang. Manusia selalu berfikir apa yang dibutuhkan oleh masyarakat mampu mereka penuhi agar kebutuhan mereka pun terpenuhi. Melihat kondisi ini ide masyarakat pun 
bermunculan, apa yang mampu mereka lakukan untuk mendapatkan penghasilan demi memenuhi kebutuhan sehari hari mereka, kemudian digelutilah profesi pengatur lalu lintas yang tak resmi tersebut yang biasa akrab dengan sapaan ' Pak Ogah" yang berdiri di sejumlah titik ruas jalan yang bertugas membantu mengatur kendaraan roda empat yang akan membelokkan mobil di persimpangan atau perputaran arah.

Menurut The Strait Times, Pak Ogah (illegal traffic wardens) adalah pengatur lalu lintas tidak resmi yang kebanyakan ditemukan di pertigaan ( $T$-junctions), di putaran jalan (U-turns) dan persimpangan rel kereta api. Sedangkan menurut Charles A. Chopel dalam bukunya Violent conflict in Indonesia Pak Ogah (illegal traffic wardens) adalah pengatur jalan illegal yang biasanya meminta upah di jalan atas jasanya mengatur lalu lintas.Keberadaan Pak Ogah dalam mengatur lalu lintas menuai pro dan kontra, pandangan yang pertama menyatakan keberadaannya sangat membantu karena dapat mengatur kekacauan lalu lintas dan dapat mengurai kemacetan sedangkan pandangan yang lain menganggap kegiatan Pak Ogah kadang kala dapat memperparah kemacetan dan bahkan melakukan tindakan-tindakan paksa untuk dibayar.Jika Persepsi Masyarakat antara mengatasi kemacetan dan tindakan ilegal memang dipengaruhi oleh karakteristik situasional, masuk akal untuk mempertimbangkan hal ini ketika menelisik adanya dukungan masyarakat terhadap Pak Ogah ataupun sebaliknya. Setelah semua, dukungan tersebut dapat mencakup penilaian kefektifan mengatasi kemacetan.

Pro kontra tindakan aksi Pak Ogah dinilai sebagai suatu pelanggaran, Pak Ogah sebagai solusi dalam mengatasi kemacetan. tanggapan atas persepsi ini disikapi oleh masyarakat dan terkait dukungan lainnya memang akan dipengaruhi oleh aspek situasi Pak Ogah itu sendiri.Fenomena "Pak Ogah" itulah yang melatar belakangi peneliti untuk mengetahui secara mendalam tentang "Persepsi Masyarakat terhadap Keberadaan Pak Ogah Kel.Gunumg sari Kec. Rappocini Kota Makassar".

\section{LANDASAN TEORI}

Setiap manusia menginginkan kehidupan yang sejahtera karena dengan kehidupan yang sejahtera dapat menghingdari manusia dari penyakit sosial, seperti kemiskinan, tuna wisma serta menghindari manusia dari keinginan untuk berbuat kejahatan, seperti pencurian, perampokan yang bertujuan untuk memenuhi kebutuhan hidupnya. Untuk mencapai kehidupan yang sejahtera tersebut setiap manusia akan berusaha dengan bekerja keras agar dapat menambah perekonomian keluarga sehingga dipilihlah pekerjaan sebagai Pak Ogah. 
Pak ogah atau yang biasa disebut juga dengan polisi cepek biasanya memanfaatkan kesemrawutan lalu lintas untuk mengambil alih peran polisi dalam mengatur lalu lintas di jalanan Ibu Kota.Apakah keberadaan Pak Ogah ini diperbolehkan berdasarkan ketentuan peraturan perundang-undangan di Indonesia.Pada dasarnya setiap orang atau sekelompok orang yang tidak memiliki kewenangan dilarang melakukan pengaturan lalu lintas pada persimpangan jalan, tikungan atau putaran jalan dengan maksud mendapatkan imbalan jasa.Kegiatan pengaturan lalu lintas ini dilakukan oleh orang perorang atau sekelompok orang yang terorganisir dengan maksud memperoleh imbalan uang.

Konsekuensi-konsekuensi objektif yang bersifat disfungsional akan menyebabkan timbulnya ketegangan atau pertentangan dalam sistem sosial. Ketegangan tersebut muncul akibat adanya saling berhadapan antara konsekuensi yang bersifat disfungsional. Dengan adanya ketegangan tersebut maka akan mengundang munculnya strukur dari yang bersifat alternatif sebagai substitusi menetralisi ketegangan.

Perlu diketahui bahwa adanya ketegangan ketegangan yang mengakibatkan adanya struktur-struktur baru tersebut akan berarti bahwa konsekuensi objektif yang bersifat disfungsional itu akan mengakibatkan adanya perubahan-perubahan sosial. Di samping itu disfungsi juga akan menyebabkan timbulnya anomie dan masalah sosial. Kenyataan tersebut juga mengandung arti timbulnya struktur-struktur baru, yang pada hakikatnya menunjukkan adanya perubahan sosial yang mengarah pada perbaikan tatanan dalam masyarakat.Prinsip-prinsip pemikiran Talcott Parsons, yaitu bahwa tindakan individu manusia itu diarahkan pada tujuan.Di samping itu, tindakan itu terjadi pada suatu kondisi yang unsurnya sudah pasti, sedang unsur-unsur lainnya digunakan sebagai alat untuk mencapai tujuan.Selain itu, secara normative tindakan tersebut diatur berkenaan dengan penentuan alat dan tujuan. Atau dengan kata lain dapat dinyatakan bahwa tindakan itu dipandang sebagai kenyataan sosial yang terkecil dan mendasar, yang unsur-unsurnya berupa alat, tujuan, situasi, dan norma. Dengan demikian, dalam tindakan tersebut dapat digambarkan yaitu individu sebagai pelaku dengan alat yang ada akan mencapai tujuan dengan berbagai macam cara, yang juga individu itu dipengaruhi oleh kondisi yang dapat membantu dalam memilih tujuan yang akan dicapai, dengan bimbingan nilai, ide, serta norma.

\section{METODE PENELITIAN}

Penelitian ini bersifat deskriptif kuantitatif, melalui Analisis data dilakukandenganmenggunakan model interaktif yakni dengan mengumpulan data, data 
dikumpulkan

dariwawancara,

observasidandokumentasi

dan

hasilnyaditulisdalambentukcatatanlapangandandisalindalambentuktranskrip.Kemudian peneliti mengeksplorasi data atau informasi yang telah dikumpulkan dari hasil observasi, wawancara dan dokumentasi tentang Persepsi Masyarakat terhadap Keberadaan Pak Ogah di Kota Makassar. Peneliti akan menganalisis data atau informasi yang dikumpulkan dari hasil observasi, wawancara dan dokumentasi yaitu dengan mengklasifikasikan data berdasarkan kriteria-kriteria tertentu yang telah ditentukan oleh peneliti kemudian membandingkan data atau informasi dari setiap sumber-sumber yang peneliti dapatkan dilapangan serta mencari hubungan antara data atau informasi yang diperoleh yang ada kaitannya dengan focus penelitian, dan terakhir penarikan kesimpulan dan verifikasi.

\section{PEMBAHASAN}

Faktor yang melatarbelakangi munculnya Pak Ogah Di Kota Makassar, diantaranya adalahKebutuhan hidup semakin hari kian meningkat,terutama yang hidup di kota-kota besar biaya hidup mereka lebih mahal di bandingkan yang di tinggal di desa, mengapa? karena segala sesuatunya hanya mampu diperoleh dengan cara di beli, kalau kata orang kota 'hidup di kota ngak ada uang = nggak makan'. Tentunya butuh usaha dan kerja untuk memenuhi segala kebutuhan sehari-hari tersebut. Namun tidak semua orang memiliki nasib yang sama, yakni sama-sama memiliki modal dan pengetahuan untuk mereka kembangkan agar menjadi modal untuk berpenghasilan. Ada beberapa orang yang butuh perjuangan keras agar mereka mampu memenuhi kebutuhannya seharihari, orang-orang yang tidak memiliki pendidikan tinggi dan pengetahuan lebih ini hanya mampu mengintai apa yang mampu mereka kerjakan agar dapat pula menghasilkan uang.

Diliriklah satu profesi ini yakni juru putar atau akrab di sapa 'Pak Ogah'” profesi ini dilirik berbagai orang yang mengaggur biasanya, karena tidak menuntut ijazah dan pendidikan tinggi untuk melakoninya, apabila telah memiliki sumpritan dan berdiri di sudut jalan dengan maksud membantu pengedara roda empat membelokkan kendraanya, maka disebutlah ia sebagai Pak Ogah atau si juru putar. Biasanya kita akan menjumpai Pak Ogah ini di setiap putaran arah jalan dengan maksud membantu pengendara mobil untuk membelokkan mobilnya tentunya jasa mereka di bayar dengan uang, biasa nya mereka diberi upah 2000 hingga 5000 rupiah.

Dalam melakukan pekerjaannya, Pak Ogah hanya bermodalkan peluit untuk mengatur kendaraan yang melintas serta topi untuk mereduksi panasnya sinar matahari 
dikala mereka bekerja pada siang hari yang terik. Dalam 1 menit sedikitnya tercatat kurang lebih 5 kendaraan yang melintas apabila sedang padat-padatnya kendaraan seperti jam pulang kantor yaitu terdiri dari mobil, truk dan sepeda motor, jam kerja pak ogah rata-rata 8 jam dalam sehari.

Faktor yang paling menonjol maraknya Pak Ogah di Kota Makassar disebabkan karena adanya peluang untuk mendapatkan uang dengan mudah dengan kondisi situasional dijalan kemudian pekerjaan Pak Ogah tersebut terbilang mudah tanpa harus membawa ijazah pendidikan untuk memperoleh pekerjaan tersebut, karena kebutuhan sehari-hari mereka yang tidak mampu di penuhi tanpa bekerja sehingga dipililah pekerjaan Pak Ogah ini, serta pengangguran karena tidak memiliki pendidikan sehingga mereka memilih untuk mengais rezeki dengan cara pintas menjadi Pak Ogah. dan tidak adanya ketegasan yang totalitas dari pihak yang berwenang untuk memberhentikan aktivitas Pak Ogah tersebut.

Ada berbagai persepsi yang muncul dengan keberadaan Pak Ogah tersebut dalam masyarakat dari berbagai golongan dan profesi, sepertipihak pengatur lalu lintas jelas mengharapkan keberadaan Pak Ogah ini tidak dibenarkan, mengingat peraturan pemerintah yang menekankan bahwa kenyamanan dan keamanan di jalan adalah yang paling utama.Dari masyarakat umum sendiri melihat keberadaan Pak Ogah ada yang pro dan adapula yang kontra.Seperti salah satu pengendara roda empat yang hampir tiap hari berjumpa dengan pak ogah ini.Keberadaan Pak Ogah terkadang membantu pengendara untuk mempermudah membelokkan kendaraannya namun terkadang pula jasa Pak Ogah ini tidak begitu di butuhkan di jalan melihat kondisi jalan yang sepi dan sangat mudah kendaraan untuk memutar arah dan kehadiran Pak Ogah di tengah jalan dalam jumlah yang terlalu banyak membuat masyarakat tidak nyaman karena bisa menuai kemacetan dan masyarakat lebih mengharapkan pihak kepolisian lalu lintaslah yang dijalan untuk menagtur lalu lintas karena merekalah yang lebih berwenang. Begitulah berbagai pendapat yang mereka ungkap sebagai pengguna jalan yang setiap saat bertemu Pak Ogah di jalan.

Kehadiran pak ogah dapat di nyatakan bahwa kehadiran pak ogah tersebut baiknya di tiadakan meski menuai banyak kontroversi dari berbagai kalangan dan pro kontra dari masyarakat namun kegiatan pak ogah tersebut tetaplah illegal.Ada beberapa teori yang dapat di kaitkan tentang persepsi masyarakat dengan penyebab munculnya pak ogah di jalan.Kehadiran pak ogah di jalan tentu menuai pro dan kontra terhadap masyrakat pada umumnya, namun demikian kegiatan tersebut tetaplah illegal dan tidak 
sah untuk dilaksanakan. Meski kita tidak melihat dampak yang begitu besar dengan hadir nya pak ogah tersebut namun tetap kehadiran pak ogah nyata kita rasakan, dan apabila di abaikan keberadaannya akan memengaruhi sistem yang ada dalam masyarakat kedepan seperti yang di ungkap pakar sosiolog dalam teorinya struktural fungsional menyatakan bahwa suatu sistem dapat beroperasi menentang fungsi-fungsi lainnya dalam suatu sistem sosial. Secara ekstrim teori ini beranggapan bahwa semua peristiwa dan semua struktur adalah fungsional bagi masyarakat.Dengan demikian pada tingkat tertentu, misalnya peperangan, ketidaksamaan sosial, perbedaan ras, bahkan kemiskinan, diperlukan oleh suatu masyarakat.Perubahan dapat terjadi secara perlahan lahan dalam masyarakat. Kalau terjadi konflik, penganut teori ini memusatkan perhatiannya kepada masalah bagaimana cara menyelesaikan sehingga masyarakat tetap dalam keseimbangan. Begitu pula yang terjadi dalam masyarakat bahwa kehadiran pak ogah dalam masyarakat tentu memiliki fungsi namun keberadaanya dapat mengganggu sistem yang ada dalam masyarakat, perlahan-lahan namun dapat membawa perubahan dalam masyarakat, sehingga dibutuhkan cara untuk menyelesaikan agar masyarakat tetap dalam keseimbangan.Pak ogah di jalan menyatakan bahwa ia melakukan aktifitas tersebut karena adanya peluang untuk seperti saat kemacetan berlangsung dan untuk mendapatkan uang dengan cara yang mudah. Tentunya kegiatan ini merupakan tindakan manusia yang telah menyalahi peraturan yang di buat oleh pemerintah.Konsekwensi yang dibuat individu tersebut kadagpula disfungsional terhadap masyarakat karena kurangnya ketegasan untuk mematuhinya seperti yang di ungakap pakar sosiolog Robert K Merton menyatakan bahwa konsekuensi-konsekuensi objektif dari individu dalam perilaku dapat bersifat fungsional dan dapat pula bersifat disfungsional. Konsekuensi objektif dari individu dalam perilaku mampu mengarah pada integrasi dan keseimbangan, sedangkan konsekuensi objektif dari individu dalam perilaku yang bersifat disfungsional akan memperlemah integrasi.

Konsekuensi-konsekuensi objektif yang bersifat disfungsional akan menyebabkan timbulnya ketegangan atau pertentangan dalam sistem sosial. Ketegangan tersebut muncul akibat adanya saling berhadapan antara konsekuensi yang bersifat disfungsional Dengan adanya ketegangan tersebut maka akan mengundang munculnya strukur dari yang bersifat alternatif sebagai substitusi menetralisi ketegangan.Perlu diketahui bahwa adanya ketegangan ketegangan yang mengakibatkan adanya struktur-struktur baru tersebut akan berarti bahwa konsekuensi objektif yang bersifat disfungsional itu akan mengakibatkan adanya perubahan-perubahan sosial. Di samping itu disfungsi juga akan 
menyebabkan timbulnya anomie dan masalah sosial. Kenyataan tersebut juga mengandung arti timbulnya struktur-struktur baru, yang pada hakikatnya menunjukkan adanya perubahan sosial yang mengarah pada perbaikan tatanan dalam masyarakat.

ProfesiPak Ogah ini bukan hanya dilakukan oleh satu atau dua pemuda saja, namun pekerjaan subsisten ini telah membuka jaringan yang mengakibatkan banyak pemuda yang tertarik dengan profesi ini terutama bagi pemuda yang tidak mempunyai keahlian di bidang pekerjaan dan para pemuda yang mempunyai pendidikan yang rendah.Jaringan ini terbentuk karena rasa solidaritas sosial yang dibentuk oleh pemuda sekitar.Rasa solidaritas tersebut muncul karena adanya persamaan nasib antar pemuda tersebut dan adanya rasa pertemanan.Menurut Durkheim, masyarakat dengan tipe yang berbeda-beda mencapai solidaritas sosial yang berbeda-beda pula. Pada masyarakat pramodern, tradisional, di mana manusia hidup dengan cara yang hampir sama satu sama lain, solidaritas dicapai sekurang-kurangnya lebih otomatis. Bentuk solidaritas mekanik ini adalah hasil dari pembagian kerja yang sederhana. Sangat sedikit peranan untuk dimainkan, atau cara hidup pun kurang bervariasi karena kebutuhan para anggota masyarakat untuk memandang dunia juga kurang lebih sama. Jaringan sosial Pak Ogah yang ada tersebut.mereka melakukan profesi tersebut secara bergantian dan mereka melakukan profesi tersebut dari pagi sampai malam hari secara bergantian seperti ada sistem kerja.Menurut pakar teori jaringan, pendekatan normatif memusatkan perhatian terhadap kultur dan proses sosialisasi yang menanamkan (internalisasi) norma dan nilai ke dalam diri aktor. Wellman mengungkapkan pandangannya bahwa analisis jaringan lebih ingin mempelajari keteraturan individu atau kolektivitas berperilaku ketimbang keteraturan keyakinan tentang bagaimana mereka seharusnya berperilaku.Karena itu, pakar analisis mencoba menghindarkan penjelasan normatif dari perilaku sosial.

\section{KESIMPULAN}

Berdasarkan hasil penelitian yang telah disajikan dalam pembahasan pada bab terdahulu, maka dapat ditarik suatu kesimpulan, sebagai berikut:

1. Kegiatan pak ogah dijalan merupakan potret kehidupan yang benar-benar ada didalam kehidupan masyarakat, meski tidak tersentuh langsung oleh semua kalangan masyarakat akan aktivitas pak ogah ini, namun jelas keberadaannya ada didalam masyarakat, beberapa di antara masyarakat mengatakan bahwa tanpa kehadiran Pak Ogah pun kendaraan mampu untuk berbelok dan masyarakat lainnya pun berpendapat bahwa dengan hadirnya Pak Ogah ini mempercepat kita untuk membelokkan 
kendaraan tanpa harus menunggu lama, bahkan dari pihak kepolisian mengatakan bahwa keberadan Pak Ogah ini hanya menuai kemacetan karena mereka mementingkan/mendahulukan yang inigin memutar arah dan pekerjaan pak ogah ini pun ilegal melihat slogan pemerintah yang terpampan di jalan bahwa masyarakat dilarang keras untuk membeli dan memberi di jalan,ini demi kenyamanan dan keamanan dijalan setidaknya ini menjadi acuan kepada masyarakat untuk merealisasikan slogan tersebut, inilah kemudian yang menjadi kontroversi dalam masyarakat, tentang adanya Pak Ogah di jalan tersebut.

2. Dalam kasus ini penelitian yang didapatkan menggambarkan bahwa bagaimana pendapat dari masyarakat dengan adanya Pak Ogah tersebut dan bagaimana seorang Pak Ogah menggantungkan kehidupannya dari upah yang diperoleh atas jasa membantu melancarkan pengendara roda empat untuk membelokkan kendaraanya, karena mereka menggangap bahwa inilah pekerjaan yang mereka mampu lakukan di luar keterbatasan pengalaman dan pengetahuan yang mereka miliki untuk mencari pekerjaan yang lebih baik adapun dari mereka yang memilih untuk bekerja sebagai Pak Ogah ini hanya untuk sekedar mencari uang semata agar mampu memenuhi kebutuhan hidupnya untuk belanja/makan sehari-hari. Jadi jelas kegiatan pak adalah illegal dan bertentangan dengan peraturan perundang-undangan yang ada.

\section{DATAR PUSTAKA}

Ikbar, Yanuar. (2012). Metode Penelitian Sosial Kualitatif. Bandung: Refika Aditama.

Kusnadi.(2006). Keberdayaan Nelayan dan Dinamika Ekonomi Pesisir. Yogyakarta: ArRuzzMedia.

Mellyhandayani, (2013), Teori-Teori Sosiologi dan Implikasinya dalam Pendidikan,https://mellyhandayanicyrus.wordpress.com/2013/02/17/265/ (Diunduh padaTanggal 1 Juni 2015, Pukul 10:49 WITA). Diakses 072015.

Moleong. Lexy. (1990). Metodologi Penelitian Kualitatif. Bandung: Remaja Rosda Karya.

Raho, Bernard. (2007). Teori Sosiologi Modern. Jakarta: Prestasi Pustaka.

Sarwono, Sarlito. (2009). Pengantar Psikologi Umum.Jakarta: Rajawali Press.

Scott, John. (2011) Sosiologi The Key Concepts. Jakarta: Rajawali Pers.

Sobur, Alex. (2003). Psikologi Umum. Bandung: Pustaka Setia. 
Stenberg, J Robert.(2008). Psikologi Kognitif. Yogyakarta: Pustaka Pelajar.

Upe, Ambo. (2010) Tradisi Aliran dalam Sosiologi. Jakarta: Rajawali Pers.

Wahyuddin. (2013). Persepsi Masyarakat Terhadap Pelaksanaan Fungsi Badan Permusyawaratan Desa (Bpd) Di Desa Fatufia Kecamatan Bahodopi Kabupaten Morowali.Kendari: Universitas Muhammadiyah

Walgito, Bimo. (2003). Psikologi Sosial. Yogyakarta: C.V Andi Offset.

Warda, (2013)Persepsi Masyarakat Terhadap Perempuan Berpendidikan Tinggi. Universitas Sriwijaya: Palembang. Skripsi. 